\title{
ОСОБЛИВОСТІ ФОРМУВАННЯ ТА ФУНКЦІОНУВАННЯ ОСВІТНІХ СЕРЕДОВИЩ В КОНТЕКСТІ ЇХ РОЛІ У ФОРМУВАННІ ІНТЕЛЕКТУАЛЬНИХ ЗДІБНОСТЕЙ
}

\begin{abstract}
Актуальність теми дослідження. Динамічний розвиток сучасного суспільства об'єктивно вимагає розширення гуманітарних знань щодо цілісного й всебічного розвитку людини. Це вказує на необхідність вивчення особливостей розумового розвитку підростаючого покоління в системі національної освіти, яка здійснює психолого-педагогічне управління розвитком молодої людини.
\end{abstract}

Постановка проблеми. Виходячи з то, що в процесі розвитку під впливом середовища у людини відбуваються зміни в залежності від характеру цього середовища, виникає методологічна проблема розробки типології різних видів освітніх просторів і середовищ.

Аналіз останніх досліджень і публікацій. Середовище фуункціонування людини завжди суттєво позначається на ї поведінці й активно впливає на інтелектуальний розвиток. Питанням організації креатитвного освітнього середовища присвячені роботи Дж. Гілфорда, Ковальчук В. У., Мажуль Л. М., Панова В. И., Полякової О. Б., Резвана О. О., Семенова І. М., Соловйової Н. В., Холодної М. О., Тихомирової Р. М., Толочек В. О., Шубіної І. В., Шумакової І. А. та ін.

Постановка завдання. Аналіз фрілософсько-психологічної літератури та здійснення огляду основних наукових шкіл щодо їх поглядів на роль освітнього середовища у формуванні інтелектуальних здібностей.

Виклад основного матеріалу. Освітній простір, у центрі якого знаходиться людина, розглядається як сукупність усіх зусиль, спрямованих на реалізацію мети освіти. Він являє собою одну зі сфер спільного простору життєдіяльності людини, що знаходиться в системі безперервної освіти. Головне завдання освіти - не формування людини за заданими зразками, а допомога в самореалізації, в розкритті та розвитку особистісного потенціалу, в прийнятті та освоєнні власної волі і відповідальності за життєві вибори, в розкритті й розвитку сутності людини, їі позитивного потенціалу.

Висновки. Останнім часом інтенсивно розвивається організаційно-середовищний підхід до соціальних процесів, з поміжних різноманітних освітніх середовищ. Так, мегасередовищем $\epsilon$ фрункціонуюча в країні система безперервної професійної освіти та інфрормаційні ресурси Інтернету, макросередовищем - освітнє середовище профрільного навчального закладу й навчальний процес у ньому. В якості мікросередовища виступають навчальні потоки й групи, предметні програми й курси, підручники та посібники, технології й стилі викладання. В останньому випадку мікро освітне середовище конституюється в організаційноконцептуальному плані тієї науково-дослідної парадигми та реалізується в технологіях, які служать вихідним предметно-методичним базисом для організації навчального процесу.

Ключові слова: освітнє середовище, організаційно-середовищний підхід; спільна навчальна діяльність; рефлексивні технології; інтелектуальні показники IQ; інтелектуальна компетентність.

V. M. Filipovych, Candidate of Psychological Sciences

\section{THE EDUCATIONAL ENVIRONMENT FORMATION AND FUNCTIONING FEATURES IN THE CONTEXT OF THEIR ROLE IN THE INTELLECTUAL ABILITIES FORMATION}

Urgency of the research. The dynamic development of modern society objectively requires the humanitarian knowledge expansion regarding the holistic and comprehensive development of a man. This indicates the need to study the characteristics of the younger generation mental development in the national education system, which carries out the psychological pedagogical management of a young person development.

Target setting. A methodological problem of developing a typology of various types of educational spaces and environments arises proceeding from the fact that in the process of development, a person undergoes changes under the influence of the environment depending on its nature. 
Actual scientific researches and issues analysis. A human functioning environment always significantly affects their behavior and actively influences intellectual development. An organization of an educational environment creation is studied in the works by J.Guilford, Kovalchuk V. U., Mazhul L. M., Panov V. Y., Poliakova O. B., Rezvan O. O., Semenov I. M., Soloviova N. V., Kholodna M. O., Tykhomyrova R. M., Tolochek V. O., Shubina I. V., Shumakova I. A., etc.

The research objective. The analysis of philosophical psychological literature and the review of the main scientific schools in their views on the role of an educational environment in an intellectual abilities formation.

The statement of basic materials. The educational space, which center is located in a man, is considered as a set of all efforts aimed at the realization of the education goal. It represents one of the spheres of the common space of human life activity, which is in the system of continuous education. The main task of education is not the formation of a man according to given patterns, but assistance in their self-realization, in discovering and developing personal potential, in accepting and mastering one's own will and responsibility for life choices, in revealing and developing the human essence, its positive potential.

Conclusions. Recently, the organizational-environmental approach to social processes, from the various diverse educational environments, is intensively developing. Thus, the megaenvironment is functioning in the country system of continuous professional education and information resources of the Internet, the macro environment is the educational environment of the specialized educational institution and the educational process in it. Teaching streams and groups, subject programs and courses, textbooks and manuals, technology and teaching styles are considered as a microenvironment. In some case, the microeducational environment is constituted in the organizational-conceptual plan of the research paradigm and is realized in technologies that serve as the initial subject-methodological basis for the organization of the educational process.

Keywords: educational environment; organizational-environmental approach; common educational activity; reflexive technologies; intellectual indicators of IQ; intellectual competence.

DOI: 10.25140/2412-1185-2019-1(13)-71-78

Актуальність теми дослідження. Вища освіта в Україні протягом останнього десятиліття знаходиться в стані безперервного й динамічного вдосконалення, метою якого є підвищення ії якості та виведення на рівень, що відповідає потребам суспільства й задовольняє потреби особистості.

Освітньому простору притаманне надзвичайне розмаїття різних видів середовищ $\mathrm{i}$ реалізованих у них послуг - від державних і приватних установ і стандартів до ексклюзивних і авторських педагогічних систем і засобів навчання й виховання, причому не тільки студентської молоді, а й дорослих фахівців. У зв'язку з цим виникає методологічна проблема розробки типології різних видів освітніх просторів і середовищ, де відбувається формування мислення й розвиток свідомості особистості.

Постановка проблеми. Соціальне середовище як сукупність суспільних і психологічних умов, у яких людина живе, позначається на ії розвитку найбільшою мірою. Тому потенційні можливості навколишнього середовища слід уміло використовувати в процесі виховання. Виходячи з то, що в процесі розвитку під впливом середовища у людини відбуваються зміни в залежності від характеру цього середовища, виникає методологічна проблема розробки типології різних видів освітніх просторів і середовищ.

Аналіз останніх досліджень і публікацій. Середовище функціонування людини завжди суттєво позначається на її поведінці й активно впливає на інтелектуальний розвиток. Питанням організації креатитвного освітнього середовища присвячені роботи Дж. Гілфрорда, Ковальчук В. У., Мажуль Л. М., Панова В. И., Полякової О. Б., Резвана О. О., Семенова І. М., Соловйової Н. В., Холодної М. О,, Тихомирової Р. М., Толочек В. О., Шубіної І. В., Шумакової І. А. та ін.. Проблема рефлексивного середовища останніми роками розглядається науковцями достатньо активно. Так, у дослідженні Т. Гури узагальнюється трактування цього поняття відповідно до його розуміння фахівцями як системи умов розвитку особистості, що відкривають для неї можливість самодослідження та самокорекції соціально-психологічних та профресійних ресурсів, основною функцією якої є сприяння виникненню потреби особистості в рефрлексії - базового 
механізму саморозвитку. Науковець визначає принципи створення рефлексивного середовища в процесі професійного розвитку фахівців: принцип унікальності, що дозволяє кожну ситуацію та особистість у ній розглядати як неповторну; принцип парадоксальності, відповідно якого підкреслюється здатність людини витримувати напруженість протиріч свого та іншого існування, прийняття їх як нормальних та таких, що задають простір вільного відповідального самовизначення; принцип відкритості, що передбачає осмислену незавершеність професійної підготовки; принцип надмірності, відповідно якого людина може розширити свої особистіснопрофресійні межі; принцип варіативності, що дозволяє слухачу та викладачеві будувати освітнє середовище на основі власних потреб та відповідно напряму свого розвитку (для рефлексивного середовища не є характерною наявність жорстко регламентованих, нав'язаних зверху методів роботи та програм).

Рефлексивне середовище, за думкою О. Деркач, виявляє себе як некерована зовнішня система, оскільки рефлексивні механізми обумовлюються процесами самоусвідомлення та саморегуляції, а відтак розвиток рефлексивного середовища не може забезпечуватись напряму зовнішніми засобами, а лише відбуватись крізь «посилення - послаблення» рефлексивних функцій через створення умов для їх культивування. Інтерес науковців до проблеми рефлексивного середовища $€$ досить високим. Слід зазначити, що поняття «рефлексивне освітнє середовище» в науці $€$ недостатньо дослідженим, однак оцінка його значущості для підготовки сучасних фахівців визначається однією із центральних проблем психологопедагогічних досліджень. Зокрема, у визначенні Ільязової Л. М. та Соколової Л. Б. рефлексивне освітнє середовище розуміється як система умов розвитку особистості, що дає їй можливість здійснювати самодослідження та самокорекцію соціально-психологічних та професійних ресурсів. Основною функцією такого середовища автори визначають здатність виникнення в особистості та групи потреби до рефлексії.

Виділення недосліджених раніше частин загальної проблеми. Незважаючи на великий обсяг наукових досліджень, у яких розкриваються питання, пов'язані з фрормуванням інтелектуальної компетентності, ще недостатньо психолого-педагогічних досліджень, присвячених вивченню формування інтелектуальної компетентності студентів в освітньому процесі, а саме в контексті врахування впливу освітнього середовища на фрормування інтелектуальних та професійних якостей майбутній фрахівців.

Постановка завдання. Аналіз фрілософсько-психологічної літератури та здійснення огляду основних наукових шкіл щодо їх поглядів на роль освітнього середовища у формуванні інтелектуальних здібностей.

Виклад основного матеріалу. Освітньому простору притаманне надзвичайне розмаїття різних видів середовищ. Безумовно, базовими $є$ нормативно освітні середовища, що належать державній системі підготовки фахівців у єдиній стандартизованій багатоступеневій системі безперервної освіти, що включає: дошкільну, шкільну, середньо-профессійну, вищу й додаткову професійну освіту. Саме на цих щаблях безперервної освіти забезпечується озброєння учнів і студентів інтелектуальним потенціалом і знаннєвими компетенціями його реалізації.

Суб'єктами освітньої діяльності вишу виступають не тільки студенти й педагоги, але також менеджери (адміністратори й керівники) навчальних закладів. Звідси випливає, що організаційно-освітнє середовище у власне людському вимірі має триступеневу структуру, утворену суб'єктами цього середовища, а саме: студентами, педагогами, менеджерами. В інформаційному вимірі організаційно-освітнє середовище характеризується тими потоками знань, які використовуються цими суб'єктами освітньої діяльності. Для студентів це суто предметно засвоювані знання, для педагогів - предметно трансльовані знання, а для менеджерів - інформаційно-організаційні знання. Останнього роду знання використовуються для постановки й вирішення складних комплексних проблем практичного управління організаційно-освітнім середовищем вишу з метою створення необхідних соціально-економічних і психолого-педагогічних умов для навчання та особистісно-професійного розвитку усіх перерахованих вище суб'єктів освітньої діяльності.

Поняття «освітнє середовище» розуміється як найближче оточення людини, у взаємодії 3 яким вона формує, розвиває й проявляє свої пізнавальні, комунікативні, соціально спрямовані якості. Компоненти середовища навчання діляться на дві частини: суб'єкти і об'єкти, де суб'єкти навчального процесу - студенти й викладачі; об'єкти - засоби навчання, методики, матеріальна 
база, сфера управління педагогічним процесом, способи навчальної діяльності. Вияв у структурі середовища суб'єктних і об'єктних компонентів має важливе значення в організації й управлінні навчально-виховним процесом, постає методологічною основою суб'єктно-об'єктних перетворень особистості людини, надає можливості кращого пристосування до будь-яких змін освітнього середовища.

Взаємодіючи з суб'єктом, освітнє середовище надає йому можливості, які являють собою єдність освітнього середовища й самої людини. Особистість набуває можливості досягнення найвищого рівня взаємодії з середовищем лише на основі освіти особистості. За характером впливу на особистість середовище може як сприяти, так і перешкоджати її становленню. Творчі можливості середовища переходять із потенційного стану в актуальний тільки в залежності від активності самої особистості й характеру використання компонентів середовища в процесі його опанування й перетворення. Професійний розвиток особистості відбувається як процес входження в професійно-освітнє середовище й інтеграції в ньому та складається 3 трьох взаємопов'язаних і взаємообумовлених етапів: адаптації, яка передбачає засвоєння діючих цінностей і норм оволодіння засобами й способами навчальної діяльності; індивідуалізації, як подолання протиріччя між необхідністю бути «таким як усі» й намаганням проявити індивідуальність; інтеграції, намагання студента бути прийнятим середовищем зі своїми особливостями й відмінностями, а також потребами освітнього середовища прийняти індивіда.

Існує низка досліджень, у яких аналізуються особливості фрормування та функціонування освітніх середовищ та їх роль у формуванні інтелектуальних здібностей. Виходячи з то, що в процесі розвитку під впливом середовища у людини відбуваються зміни в залежності від характеру цього середовища, одні автори під «розвивальним освітнім середовищем» розуміють такий стан (субстанцію) освітнього середовища, взаємозв'язок компонентів якого дозволяє людині динамічно проходити наступні фрази розвитку: об'єктну, суб'єктно-функціональну, суб'єктну, перетворення, тим самим переходити із одного якісного стану розвитку в інший [1]. Як більш високий рівень розвивального освітнього середовища інші автори виділяють «креативне освітнє середовище». Це такий стан освітнього середовища (інтелектуального), взаємозв'язок компонентів якого дозволяє людині проходити крім названих вище фаз ще й такі, як розвиток здібностей до виявлення й постановки проблем; здібність до генерування більшого числа ідей; гнучкість (здібність продукувати різнобічні ідеї); оригінальність (здібність відповідати нестандартно); здібність удосконалювати об'єкт, додаючи деталі; здібність вирішувати проблеми. Тобто те, що називаємо інтенціональністю [2].

Як відомо, індивід будує ментальну модель ситуації на основі інтенціональності, тобто здатності репрезентувати світ самому собі: в когнітивній системі існує інтенціональна готовність відповідати на відповідну ситуацію відповідним чином [3]. Під інтенціональністю розуміється весь модальний спектр, який пронизує всі рівні індивідуальності й виражає наміри, програму реалізації й оцінку результату, тобто це поняття виходить з уявлення про спряженість індивідуалізованих ментальних моделей світу й знань про себе, яка проявляється у феноменології переживання себе як набутого досвіду, включеного в події, ініціюючого взаємодію. Інтенціональність психіки означає взаємопроникнення суб'єктивного досвіду й об'єктивної реальності, тобто позначає перехід від світу фрізичних об'єктів до світу ментальних феноменів. Інтенція в дії полягає „в переживанні діяння”, в репрезентації себе на рівнях самоприналежності, самоагентності, самопізнання [3, с. 37].

У просторі біологічної, соціальної й семантичної взаємодії виникають відносини одного до одного (спочатку на емоційно-ціннісній основі), які потім переносяться на предмет дії/взаємодії. Потреба в другому реалізується в процесах, технологіях і результатах діяльності, а результати взаємодії підсилюють потреби партнерів-суперників. Така організація навчального процесу сприяє активізації глибинних сил людини (потреб і здібностей), виведенні їх назовні (екстериоризовувати), робить цей процес максимально керованим та спрямованим на вдосконалення особистості.

На сьогодні існують дослідження, в яких розроблена система теоретичних положень які пояснюють «сумісну інтелектуальну діяльність», визначені основні її складові та модератори, які впливають на прояв інтелекту й креативності: характер міжособистісних відносин, особистісні особливості учасників діяльності та характер розподілу ролей між ними. Тобто, вплив 
ситуаційних змінних і міжособистісних відносин на прояви інтелекту й креативності. В інших дослідженнях показано розвиток інтелекту та креативності в умовах соціального середовища.

Творчість студента при цьому завжди $€$ показником високого рівня розвитку освітнього середовища, а тому судити про його стан можна по тому, наскільки воно сприятливе для реалізації творчих сил особистості, для творчої самореалізації студента. 3 іншого боку, можливості досягнення високого рівня взаємодії з середовищем, залежать від відповідного рівня освіченості людини. Адже чудове оточення не само по собі діє на будь-яку людину, стимулюючи її креативність. Інновації не народжуються автоматично, а для цього потрібний ще й «підготовлений розум», і тоді в прекрасному оточенні креативна людина знаходить нові зв'язки серед ідей, бачить ситуацію в цілому, нові перспективи її вирішення. Можна сказати, що освітнє середовище - система впливів і умов формування особистості згідно заданого зразку, можливість її розвитку, яка містяться в просторово-предметному й соціальному довкіллі. Ця система включає три компоненти: просторово-предметний, як певне фізичне оточення; психодидактичний, як спеціальні програми навчання; соціальний, як особливі людські чинники [4]. Воднораз, взаємодіючи з суб'єктом, освітнє середовище надає йому можливості, які являють собою єдність освітнього середовища й самої людини.

У середині освітнього середовища, як особливе в загальному чи індивідуальне в особливому, формується «акмеологіне середовище». Це середовище утворюється у відповідності 3 основними принципами особистісно-орієнтованого підходу, з урахуванням психофрізіологічних, індивідуально-психологічних, особистісних особливостей суб'єктів освітнього процесу з метою оптимізації процесу їх розвитку й саморозвитку, забезпечуючи успішність їх акмеорієнтованих самозмін. Воно сприяє формуванню й розвитку особистісних новоутворень і значною мірою визначає саморозвиток і самоефективність особистості та її духовне збагачення на відповідних етапах життєвого шляху [5].

Середовище як акмеформа може проявлятися різнобічно, як: здійснення одночасно ціннісносмислового самовизначення, самоефективності та самореалізації духовної сутності людини; аттрактор стійкої рівноваги людини в якості біопсихосоціальної істоти, завдяки мобілізації всіх життєвих сил людини у відносно нормальних умовах середовища; результат еволюційного розвитку, який $є$ вищим рівнем розвитку людини й як результат надпорогових реакцій, що забезпечують виживання чи досягнення мети в екстремальних умовах; динамічний феномен, який завжди проявляється в поведінці людини та видатних досягненнях її діяльності, які стають можливими за впливу високої мотивації досягнень [6].

Звісно, перераховані ознаки проявляються у відносно нормальних середовищних параметрах, де якісне удосконалення середовища надає розвитку людини новий імпульс. Взаємодія із запропонованим акмеологічним середовищем передбачає наявність якостей відповідних середовищу. На разі маються на увазі якості креативного, оздоровчого освітнього середовища, спрямованого на формування інтелектуальної компетентності, особистості майбутнього фахівця та його здоров'я. В основі розроблюваної нами моделі акмеологічного середовища лежить концепція, згідно якої учасники професійно-освітнього процесу вузу знаходяться в акмоенергоінформаційній взаємодії. Регулятором їх взаємодії й взаємовідносин є результат, який у підсумку має бути отриманий і який одночасно є засобом узгодження їх подальших дій у процесі колективного, групового й індивідуального спілкування. Очевидно, ідеалізовані продуктивні моделі результатів беруть участь у створенні акместратегій і акметехнологій розвитку готовності студентів до майбутньої професійної діяльності.

Акместратегія - система організації професійного освітнього середовища, завдань у розрахунку на прогнозовані результати навчання студентів у вигляді ознак їх творчої готовності до майбутньої діяльності, яка забезпечує їм подальший саморозвиток, професійну самоефективність у нових умовах. Безумовно, професійне навчання - це й є професія. В освіти не існує межі насичення - так само в освітнього середовища відсутній кінцевий пункт трансформації, є певний ідеальний образ (за Б.Г. Ананьєвим) і постійно здійснювані переходи від реального до ідеального.

Слід зазначити, що практика роботи сучасної вищої освітньої установи набуває значних змін: вимоги до організації навчального процесу, скорочення годин на вивчення навчальних дисциплін тощо. Але найсуттєвіше в цих змінах це зміна цільової парадигми - від парадигми «пасивного знання» до «знань активних, творчо-розвивальних» - 3 передбачуваним, безумовно, 
обов'язковим моментом «уміння». За таких умов студент самостійно має «видобувати» собі знання, а викладачі повинні допомогти йому набути вміння навчатися. У ситуації, що склалася у вишах країни, саме вміння навчатися має пріоритетне значення в набутті професійної компетентності і, на нашу думку, включає дві складові: рефллексивну - здібність визначати, яких саме знань і вмінь їм не вистачає, і пошукову - здібність знаходити й засвоювати відсутні знання і вміння. Безумовно, виникає необхідність побудови критеріїв вимірювання в студента обох складових уміння навчатися [7 ].

При створенні акметехнологій вчені також враховують середовище як першорядний чинник, який певним чином й уможливлює ці технології: при створенні акмеологічного середовища в студентському колективі, коли престижно добре навчатися й прагнути до творчості, оригінальне рішення має суспільну значущість і сприяє підвищенню соціального статусу студента; при забезпеченні єдності акмеологічного середовища й діяльності на кожному етапі саморозвитку в структурі навчального процесу, за рахунок динаміки пізнавальних завдань у системі навчальних фрорм при зростанні чи зниженні міри складності з визначенням «зони успіху» у кожного студента.

За дотримання наведених принципових положень і умов створення акмеологічного середовища взаємодія його й особистості стає активним силовим потенціалом, який впливає на розвиток особистості. Перетворювальне акмеологічне середовище здійснює трансформації особистості за рахунок впливу на її мотиваційну сферу. У деяких дослідженнях висловлюється гіпотеза про те, що способи задоволення потреб спеціалізують особистість і, фрормуючи сферу потреб і підструктур «Я», допомагають фріксувати в особистості норми певного соціуму, стабілізуючи одночасно цей соціум [8]. На основі цього фрормується мотивація роботи в покращеному середовищі.

Акмеологічному середовищу відповідає такий набір якостей студента: намагання усвідомити й реалізувати свій особистісний потенціал, створення позитивного образу «я»; намагання належати до співтовариства професіоналів»; усвідомлювати себе як особистість, рефлексивне відношення до себе, уміння бачити саме суттєве в своїй особистості, навчанні й житті; намагання допомагати іншим як мета життя, організовувати співробітництво як стиль життя й здійснювати творчі дії як зміст мети життя; поява установки на позитивну зміну середовища й соціальної ситуації [8]. Безумовно, перераховані якості проявляються в параметрах середовища, й якісне удосконалення яких має надавати розвитку людини новий імпульс.

Перший тип акмеологічного середовища - середовище, що формується з появою перших ознак «акме», під яким розуміється психічний стан, що означає вищий для даної людини рівень у її професійному розвитку на даний час і передбачає максимальну змобілізованість, реалізованість усіх професійних здібностей, можливостей і резервів людини на конкретному етапі життя.

Другий тип - перетворююче акмеологічне середовище (яке має розвивальний ефект), де діяльність викладача й студентів розуміється як сумісна, активна, професійно освітня. Взаємодія починає носити акмеологічний характер, коли поведінка кожного із них як особистостей і діяльність як суб'єктів знаходить своє втілення в кінцевому результаті [9, с. 141].

Існує поняття «рефлексивне освітнє середовище», яке дуже близьке поняттю «групова рефлексивність як таке, що сприяє здійсненню особистістю та групою самодослідження та самокорекції соціально-психологічних та професійних ресурсів. На основі різних наукових підходів до визначення особливостей освітнього рефлексивного середовища, виокремлено їх авторське бачення: наявність усвідомленої потреби в рефлексії процесу та результатів діяльності як у викладача, так і в студента; стимулювання суб'єктів середовища до самозміни відповідно до занурення в контекстні навчально-професійної ситуації; кооперативність у набутті та переданні досвіду; високий рівень комфортності навчання. Визначено, що рефлексивне середовище має бути інформаційно надлишковим, оскільки надлишковість та недостатність сприяють неоднорідності середовища, що стає умовою рефлексивного розвитку особистості. Доведено, що створення рефлексивного середовища в навчальному процесі ВНЗ дозволяє спрямовувати студентів до спеціальним чином організованої рефлексії навчально-професійної діяльності відповідно до зіставлення ії із реальною професійною практикою, що сприяє усвідомленню ними можливості перенесення рефлексивного досвіду в професійну сферу.

Рефлексивне середовище дозволяє вирішувати професійні (навчально-професійні) завдання через взаємодію інтелектуальних зусиль партнерів професійного спілкування, внаслідок чого виникає ситуація сумісного мисленнєвого пошуку, а активізація рефлексивних компонентів 
дозволяє визначати динаміку структури пізнавальної активності суб'єктів взаємодії, а відтак - їі продуктивності. На відміну від класичного підходу до підготовки фахівця у вищій школі, коли він мав бути готовим до дій та операцій у межах заданої цілі без її рефлексії, сучасна освіта призначена спрямувати майбутніх фрахівців до діяльності в умовах, коли ціль обумовлюється сенсом, а в людини $€$ можливість вибору. Отже, йдеться про фрормування рефлексивних здібностей студентів не лише на рівні процесів пізнання та комунікації, але й на рівні цілей. Такий підхід до фахової підготовки вимагає створення рефлексивного навчально-пізнавального середовища в навчальному просторі вишу.

Рефлексивне освітнє середовище розуміється як система умов розвитку особистості, що дає їй можливість здійснювати самодослідження та самокорекцію соціально-психологічних та профресійних ресурсів. Основною функцією такого середовища автори визначають здатність виникнення в особистості та групи потреби до рефлексії Можна визначити чинники, що пригнічують рефлексію в процесі навчання: установка на знання безвідносно до практичної професійної діяльності; ідеологія культу джерел знань з неприйняттям ідей сумніву; ідеологія норми, неприйняття можливості її перегляду. Саме некритичне ставлення до норми можна вважати основою антирефлексивності, оскільки ідеологія нормативності змушує людину в процесі діяльності не мислити, досліджувати, а відшукувати правильну відповідь з тих, що були надані різними авторитетними джерелами. Водночас рефлексивне середовище розвиває свободу думки та діяльності майбутнього фахівця, надає йому умови для індивідуальної рефлексії та розвитку групової рефлексивності при здійсненні пізнавальної, а потім професійної діяльності. Отже, реалізація принципу свободи в рефлексивному навчально-пізнавальному середовищі є однією із умов професійного становлення майбутнього фахівця.

Проблеми реалізації середовищного підходу, пов'язаного з феноменом рефлексивноконктекстного освітнього середовища, представлені в дослідженні Желанової В. В. [10]. Тут звертається увага на багаторівневій педагогічно організованій системі умов та можливостей, а також засобів освіти, які забезпечують упровадження професійного контексту в систему підготовки фахівців. В умовах такого середовища, за думкою автора, людина одночасно виступає його продуктом і творцем, а трансформація навчальної діяльності в професійну відбувається найбільш активним способом. Науковець визначає фрази формування даного типу освітнього середовища: адаптації майбутнього фахівця до умов середовища та активного відтворення впливу на середовище.

Цікавою видається також думка автора щодо характеристик рефлексивно-контексного середовища, серед яких окремо визначаються: імерсивність (від англ. immersion «занурення»), що представляється як ілюзія знаходження у взаємодії із середовищем, яке наближається до реального, тобто в наближенні умов середовища до майбутньої професійної діяльності; присутність, що в загальному розумінні відбиває досвід людини знаходитись в одному місці навколишнього середовища, водночас фрізично знаходячись в іншому місці (в контекстнорефлексивному середовищі присутність визначає відчуття присутності в професійному середовищі при безпосередньо фрізичному знаходженні в навчальній аудиторії); інтерактивність - ступінь, до якої є можливою участь користувачів у зміні й формуванні змісту середовища, у відносинах особистості й середовища, які є суб'єктами у ставленні один до одного, що надає можливість середовищу розширюватись та збагачуватись, тим самим утворюючи професійний контекст становлення майбутніх фахівців.

Висновки. Останнім часом інтенсивно розвивається організаційно-середовищний підхід до соціальних процесів, з поміжних різноманітних освітніх середовищ. Так, мегасередовищем $є$ функціонуюча в країні система безперервної професійної освіти та інформаційні ресурси Інтернету, макросередовищем - освітнє середовище профрільного навчального закладу й навчальний процес у ньому. В якості мікросередовища виступають навчальні потоки й групи, предметні програми й курси, підручники та посібники, технології й стилі викладання. В останньому випадку мікро освітнє середовище конституюється в організаційно-концептуальному плані тієї науково-дослідної парадигми та реалізується в технологіях, які служать вихідним предметно-методичним базисом для організації навчального процесу.

У реальному житті постійно відбувається процес перетворення середовища освіти в освітнє середовище. Середовище освіти об'єктивне, й абітурієнт входить у нього як особистість 3 власним внутрішнім середовищем і початковими компетенціями. Стає об'єктивно необхідним 
об'єкт - суб'єктне перетворення, в якому одночасно закладена сутність як педагогічної діяльності самого студента, так і його відносин 3 середовищем. Відбувається якби «персоналізація середовища» - фріксація певної частини середовища як свого «Я». Можна говорити, що освітнє середовище - сукупність соціокультурних зв'язків учасників освітнього процесу, відповідних освітній діяльності й відносинам, включаючи ті з них, у яких особистість майбутнього фахівця виконує певну роль, має свій статус, виступає як суб'єкт суспільно значущої діяльності й має можливості задовольняти свої індивідуальні потреби.

\section{Література}

1. Мажуль, Л. Н. Креативная среда в информационном обществе / Л. А. Мажуль // Мир психологии. - 2013. - № 4. - С. 148-165.

2. Семенов, И. Н. Рефрлексивно-развивающие среды формирования мышления и самосознания субъектов образования / И. Н. Семенов // Мир психологии. - 2013. - № 4. - С.81- 96.

3. Шмаргун, В. М. Психосоматичні особливості в інтелектуальному розвитку дітей: [монографія] / В. М. Шмаргун. - К. : Університет „Україна”, 2009. - 471с.

4. Чепелєва, Н. В. Соціально-психологічні чинники розуміння та інтерпретації особистого досвіду: монографрія / Н. В. Чепелєва, Т. М. Титаренко, М. Л. Смульсон та ін. ; за ред. Н. В. Чепелєва. - К. : Педагогічна думка, 2008. - 255 с.

5. Деркач, А. А. Акмеологические основы развития профессионала / А .А. Деркач. - М. : Изд-во Московского психолого-социального института; Воронеж, «МОДЭК», 2004. - 752 с.

6. Шумакова, И. А. Понятие «рефлексивная образовательная среда» в философии образования / И. А. Шумакова //. Научные ведомости. - 2008. - № 4. -- С. $64-75$.

7. Старовойтенко, Е. Б. Современная психология: формы интеллектуальной жизни: учебник для высш. школы / Е. Б. Старовойтенко. - М. : Акад. Проект, 2001. - 538 с.

8. Деркач, А. А. Акмеологические основы развития профессионала / А. А. Деркач. - М. : Изд-во Московского психолого-социального института; Воронеж, «МОДЭК», 2004. - 752 с.

9. Тихомирова, Т. Н. Межличностное общение в социальной среде и развитие общих способностей / Т. Н. Тихомирова // Психологический журнал. - 2011. - Т. 32, № 6. - С. 30 - 40.

10. Желанова, В. В. Динаміка середовищеутворення в технології контекстного навчання майбутнього вчителя початкових класів / В. В. Желанова // Педагогічний процес: теорія і практика. - 2014. - Вип. 4. - С. 27-32.

\section{References}

1. Mazhul, L. N. (2013). Kreativnaia sreda $v$ informatsyonnom obshchestve [Creative environment in the information society]. Mir psikhologii - World of psychology, 4, 148-165 [in Russian].

2. Semenov, I. N. (2013). Refleksivno-razvivaiushchie sredy formirovaniia myshleniia i samosoznanyia subektov obrazovanyia. [Reflexive and developing environments for the formation of thinking and self-awareness of the subjects of education]. Mir psikhologii - World of psychology, 4, 81-96 [in Russian].

3. Shmarhun, V. M. (2009). Psykhosomatychni osoblyvosti v intelektualnomu rozvytku ditei [Psychosomatic features in the children's intellectual development]. Kyiv: Universytet „Ukraina” [in Ukrainian].

4. Chepelieva, N. V., Tytarenko, T. M., Smulson, M. L. (2008). Sotsialno-psykholohichni chynnyky rozuminnia ta interpretatsii osobystoho dosvidu [Socio-psychological factors of understanding and interpretation of personal experience]. Kyiv: Pedahohichna dumka [in Ukrainian]

5. Derkach, A. A. (2004). Akmeologicheskie osnovy razvitiia professionala [Acmeologycal bases of professional development]. Moscow: Izd-vo Moskovskogo psihologo-sotsialnogo instituta; Voronezh, «MODEK» [in Russian].

6. Shumakova, I. A. (2008). Ponyatie "refleksivnaya obrazovatel'naya sreda» v filosofii obrazovaniya [The notion of "reflexive educational environment" in the philosophy of education]. Nauchnye vedomosti - Scientific reports, 4, 64-75 [in Russian].

7. Starovoytenko, E. B. (2001). Sovremennaya psikhologiya: formy intellektualnoy zhizni [Contemporary psychology: forms of intellectual life]. Moscow: Akad. Proekt [in Russian].

8. Derkach, A. A. (2004). Akmeologicheskie osnovy razvitiia professionala [Acmeologycal bases of professional development]. Moscow: Izd-vo Moskovskogo psihologo-sotsialnogo instituta; Voronezh, «MODEK» [in Russian].

9. Tikhomirova, T. N. (2011). Mezhlichnostnoe obshchenie $v$ sotsialnoy srede i razvitie obshchikh sposobnostey [Interpersonal communication in social environment and development of common abilities]. Psikhologicheskiy zhurnal - Psychological journal, 32(6), 30-40 [in Russian].

10. Zhelanova, V. V. (2014). Dynamika seredovyshcheutvorennia $v$ tekhnolohii kontekstnoho navchannia maibutnoho vchytelia pochatkovykh klasiv [The dynamics of the formation of environment in the technology of contextual education of the future teacher of elementary school]. Pedahohichnyi protses: teoriia i praktyka - Pedagogical process and practice, 4, 27-32 [in Ukrainian].

Надійшла 10.06.2019

Бібліографічний опис для цитування:

Філіпович, В. М. Особливості формування та функціонування освітніх середовищ в контексті їх ролі у формуванні інтелектуальних здібностей / В. М.Філіпович // Проблеми соціальної роботи: філософія, психологія, соціологія. - 2019. - № 1 (13). - С. 71-78. 